\title{
Sarcocystis neurona Transmission from Opossums to Marine Mammals in the Pacific Northwest
}

\author{
Alice M. O’Byrne, ${ }^{1}$ Dyanna M. Lambourn, ${ }^{2}$ Daniel Rejmanek, ${ }^{3}$ Katherine Haman, ${ }^{2}$ \\ Michael O’Byrne, ${ }^{4}$ Elizabeth VanWormer, ${ }^{5}$ and Karen Shapiro ${ }^{6}$ \\ ${ }^{1}$ School of Veterinary Medicine, University College Dublin, Belfield, Dublin D04 W6F6, Ireland \\ ${ }^{2}$ Wildlife Program, WA Department of Fish and Wildlife, 1111 Washington Street SE, Olympia, WA 98501 \\ ${ }^{3}$ California Animal Health and Food Safety Laboratory, Davis, CA \\ ${ }^{4}$ University of Göttingen, Wilhelmsplatz 1, 37073 Göttingen, Germany \\ ${ }^{5}$ School of Veterinary Medicine and Biomedical Sciences, School of Natural Resources, University of Nebraska-Lincoln, Lincoln, NE \\ ${ }^{6}$ Pathology, Microbiology and Immunology, University of California Davis, One Shields Avenue, 4206 VM3A, Davis, CA 95616-5270
}

\begin{abstract}
Increasing reports of marine mammal deaths have been attributed to the parasite Sarcocystis neurona. Infected opossums, the only known definitive hosts, shed S. neurona sporocysts in their feces. Sporocysts can contaminate the marine environment via overland runoff, and subsequent ingestion by marine mammals can lead to fatal encephalitis. Our aim was to determine the prevalence of $S$. neurona in opossums from coastal areas of Washington State (USA) and to compare genetic markers between S. neurona in opossums and marine mammals. Thirty-two road-kill opossums and tissue samples from 30 stranded marine mammals meeting inclusion criteria were included in analyses. Three opossums $(9.4 \%)$ and twelve marine mammals $(40 \%)$ were confirmed positive for $S$. neurona via DNA amplification at the ITS1 locus. Genetic identity at microsatellites (sn3, sn7, sn9) and the snSAG3 gene of S. neurona was demonstrated among one harbor porpoise and two opossums. Watershed mapping further demonstrated plausible sporocyst transport pathways from one of these opossums to the location where an infected harbor porpoise carcass was recovered. Our results provide the first reported link between S. neurona genotypes on land and sea in the Pacific Northwest, and further demonstrate how terrestrial pathogen pollution can impact the health of marine wildlife.
\end{abstract}

Keywords: Sarcocystis neurona, Marine mammals, Transmission, Watershed, Groundwater, Opossums

\section{INTRODUCTION}

Sarcocystis neurona is a protozoan parasite with a life cycle that includes both definitive and intermediate hosts.

Supplementary Information: The online version contains supplementary material available at https://doi.org/10.1007/s10393-021-01536-w.

Published online: July 2, 2021

Correspondence to: Karen Shapiro, e-mail: kshapiro@ucdavis.edu
Intermediate hosts include equines, felines and marine mammals such as sea otters (Enhydra lutris), harbor seals (Phoca vitulina), harbor porpoise (Phocoena phocoena), sea lions (Eumetopias jubatus), pygmy sperm whales (Kogia breviceps) and Pacific white-sided dolphins (Lagenorhynchus obliquidens) (Mullaney et al. 2005; Dubey et al. 2000; Barbosa et al. 2015). The opossum (Didelphis virginiana), the only known definitive host for S. neurona, consumes sarcocysts via ingestion of infected intermediate 
host tissue. Sexual replication of the parasite in the intestinal tract of opossums leads to formation of oocysts that contain 2 sporocysts. Oocysts and sporocysts are then passed into the environment in feces (Dubey et al. 2001; Fenger et al. 1995).

In intermediate hosts, $S$. neurona can encyst in muscle or central nervous system (CNS) tissue without causing clinical signs (Dubey et al. 2001). However, encephalitis can result in some animals infected with $S$. neurona, with strain type likely mediating the virulence of this pathogen (Barbosa et al. 2015; Wendte et al. 2010b). Sarcocystis neurona is a causative agent of equine protozoal myeloencephalopathy (EPM) (Dubey et al. 1991) and has been increasingly implicated in marine mammal mortality (Thomas et al. 2007; Miller et al. 2010; Barbosa et al. 2015). For the related protozoan parasite, Toxoplasma gondii, several studies have suggested that oocysts can become mobilized via overland runoff into coastal waters, with subsequent concentration in marine invertebrates that can serve as a source of infection to marine mammals (Arkush et al. 2003; Miller et al. 2004; Conrad et al. 2005; Shapiro et al. 2012, 2014; Schott et al. 2016). Studies of ground and surface water has confirmed the presence of $T$. gondii DNA (Bahia-Oliveira et al. 2017).

Of particular importance is the fatality associated with S. neurona infection in federally listed species such as the threatened Southern sea otter (Enhydra lutris nereis) (Kreuder et al. 2003; Miller et al. 2010, 2018). In 9.8\% of sea otters $S$. neurona infection was attributed as the primary cause of death (Thomas et al. 2007). In Washington State
(USA), S. neurona was recently identified as the leading cause of death in Northern sea otters (Enhydra lutris kenyoni), with $30 \%$ of animals $(N=93)$ examined between 2002 and 2015 dying due to S. neurona encephalitis (White et al. 2018). An earlier investigation demonstrated that $61.5 \%(n=161)$ of marine mammal carcasses in the Pacific Northwest were infected with S. neurona, and the relative frequency of these infections had increased from 2004 to 2009 (Gibson et al. 2011).

The overarching goal of this study was to investigate the molecular epidemiology of $S$. neurona from terrestrial to marine mammals in the Pacific Northwest. Specifically, our aims were to (1) analyze gastrointestinal (GI) scrapings from opossums from western Washington State to evaluate the prevalence of animals shedding $S$. neurona; (2) test marine mammal tissues for the presence of $S$. neurona infection; and (3) use molecular signatures to compare $S$. neurona strains present in opossums and marine mammals in this region.

\section{Materials and Methods}

\section{Marine Mammal and Opossum Sample Collection}

Tissues from 30 marine mammals were collected from animals that stranded along coastal regions of Washington State, USA, between 2015 and 2017 (Fig. 1). Carcasses were opportunistically collected by the Washington Department of Fish and Wildlife (WDFW) and the Cascadia Research Collective as part of a coastal health monitoring program

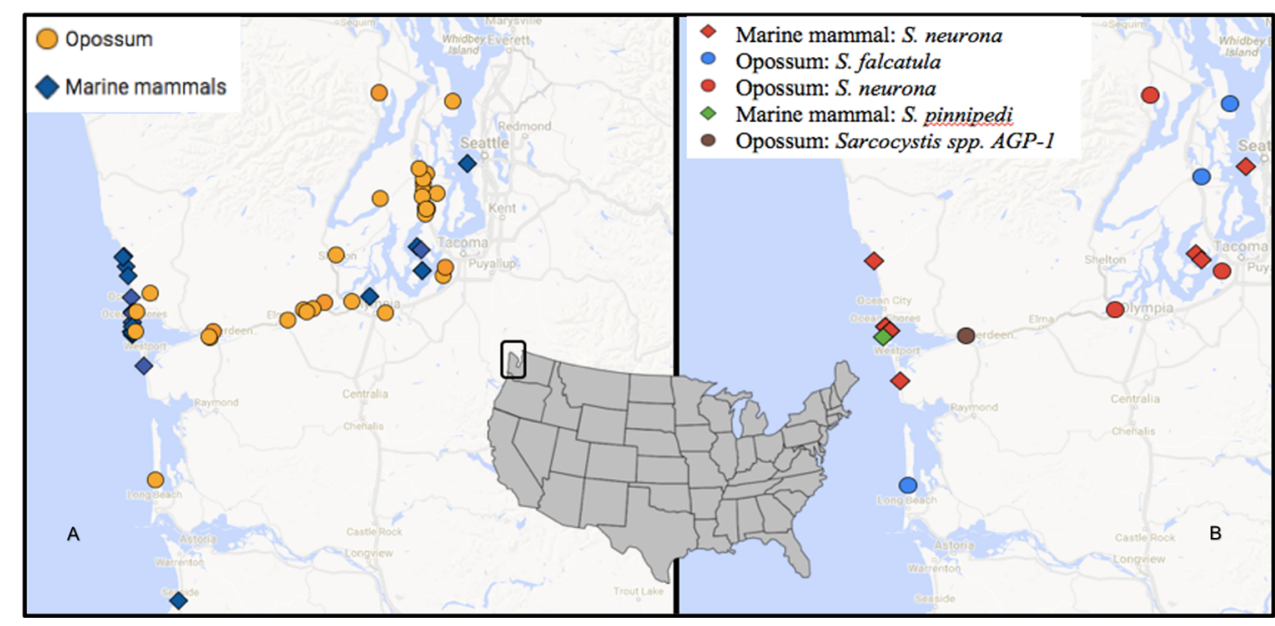

Figure 1. Map detailing the sampling sites of animals collected from western Washington State, USA between 2015 and 2017 . a Location of all marine mammals (blue diamonds) and opossums (orange circles) analyzed for the presence of Sarcocystis spp. DNA. b Confirmed Sarcocystis spp. infections in marine mammals (diamonds) and opossums (circles). Inset map indicates the sampling area within the USA. 
by the West Coast Marine Mammal Stranding Network [Marine Mammal Protection Act Stranding Agreements and Section 109(h), 16 U.S.C 1379(h)]. Tissue samples that were collected included brain, skeletal and cardiac muscle, liver and lymph node. Marine mammal species, collection dates, location, tissue type analyzed, live stranding and histopathological categorization are listed in Table S1. Pregnant marine mammals that had unborn fetuses are indicated as pairs with the suffix "F" denoting the fetus. Marine mammal inclusion criteria for this study were (1) confirmed or suspected protozoal encephalitis based on previous histopathological analysis; (2) evidence of protozoal infection outside of the central nervous system; (3) live stranding events with evidence of neurological abnormalities; and (4) carcasses for which histopathology was not available if animals were recovered from areas where recent confirmed encephalitis cases were encountered or during months when increased cases of protozoal encephalitis have been previously described (April-June; White et al. 2018).

Opossum carcasses were opportunistically collected following identification of individual animals killed along roadways in coastal Washington by the WDFW and Cascadia Research Collective. Carcasses were frozen at $-20^{\circ} \mathrm{C}$ and thawed at $4^{\circ} \mathrm{C}$ for $48 \mathrm{~h}$ prior to processing. Carcasses were dissected and the gastrointestinal tract was exposed. The small intestine was removed distal to the pylorus and proximal to the caecum. Working in 3-inch segments, the intestine was flushed of ingesta using phosphate-buffered saline (PBS), cut lengthwise and the inner mucosal layer was scraped with the edge of a glass slide. GI scrapings were collected in a sterile 15-ml container and shipped on dry ice from the WDFW to the University of California, Davis for molecular analysis.

\section{Opossum GI Scrapings: Sporocyst Visualization and Molecular Identification}

GI scrapings were examined via direct brightfield microscopy at $400 \times$ magnification for the presence of sporocysts. Scrapings containing sporocysts were washed in $10 \mathrm{ml}$ PBS three times $(1000 \times \mathrm{g} 10 \mathrm{~min})$, agitated in $2.6 \%$ sodium hypochlorite for five minutes, followed by three additional PBS washes (Rejmanek et al. 2009). The resulting pellet was frozen at $-20^{\circ} \mathrm{C}$ until further processing.

For DNA extraction, sporocyst pellets were initially subjected to one freeze-thaw cycle performed via $5 \mathrm{~min}$ immersion in liquid nitrogen followed by $5 \mathrm{~min}$ in boiling water. A Qiagen $^{\mathrm{TM}}$ tissue extraction kit (Qiagen, Valencia,
CA) was used to extract nucleic acids, following manufacturer recommendations, with the exception of adding $40 \mu \mathrm{l}$ proteinase $\mathrm{K}$ in the initial incubation. For DNA amplification, a nested primer set (ITS1-500) targeting a $500 \mathrm{bp}$ fragment of the Internal Transcribed Spacer 1 (ITS1) gene, which is specific for Sarcocystis falcatula and S. neurona but does not amplify other Sarcocystis spp. or T. gondii, was used (Miller et al. 2009). Primer sequences are listed in Table S2, and PCR conditions were followed according to the references listed for each primer set. PCR products were separated on a $1.5 \%$ agarose gel stained with ethidium bromide and visualized using ultraviolet light. Amplification products consistent in size with a $S$. neurona-positive control sample were excised and DNA was purified with Qiagen $^{\text {TM }}$ QIAquick Gel extraction kit (Qiagen, Valencia, CA) following manufacturer instructions. Purified DNA samples were submitted to the University California Davis Sequencing Facility. For sequence analysis, the forward and reverse sequences were aligned (Geneious software, Biomatters, Auckland, New Zealand), ends trimmed and the consensus sequence compared with GenBank reference sequences using BLAST (http://blast.ncbi.nlm.nih.gov/Bla st.cgi).

\section{Marine Mammal Tissues: Nucleic Acid Extraction and Amplification}

Marine mammal tissues were dissected and placed into a 1.5-ml Eppendorf tube. DNA extraction was performed using the Qiagen ${ }^{\mathrm{TM}}$ tissue extraction kit (Qiagen, Valencia, CA) following manufacturer instructions. The extracted DNA was amplified using the IST1-500 assay as described above, and/or a less specific nested primer set targeting the ITS1 region that can co-amplify other protozoan parasites, including other Sarcocystis species and T. gondii (Miller et al. 2009). Due to fiscal constraints, 10 samples were tested using the ITS1-500 assay, and 20 samples were tested using the ITS1 assay-providing data on both Sarcocystis and $T$. gondii prevalence in these 20 samples. PCR amplification products consistent with positive controls [S. neurona ( $\sim 1100 \mathrm{bp})$ or T. gondii $(\sim 500 \mathrm{bp})$ ] were excised, purified and submitted for sequence analysis as described above.

\section{Molecular Characterization of S. neurona}

Samples that were confirmed as S. neurona via sequence analysis were further characterized using four genetic 
markers (Rejmanek et al. 2009, 2010). The selected markers included one surface antigen gene (snSAG3) and three microsatellite markers (sn3, sn7 and sn9) that have shown moderate-high polymorphism in previous investigations (Rejmanek et al. 2010). Primer sequences and thermocycler conditions for each assay are listed in Table S2. The number of dinucleotide repeats was recorded for each of the microsatellites, while for snSAG3 analysis, the nucleotide positions which differed from a $S$. neurona consensus sequence (GenBank sequence GQ386977) were identified as single nucleotide polymorphisms (SNPs).

\section{Watershed Delineation and Groundwater Contours}

Basic hydrogeological mapping was performed to establish a conservative waterborne transport pathway from land to sea. For this modeling scenario, we assumed that $S$. neurona sporocysts have similar environmental transport properties as Toxoplasma gondii oocysts, a related apicomplexan parasite known to travel in both groundwater and surface water (Bahia-Oliveira et al. 2017). Both groundwater and surface water mapping were performed as $T$. gondii has been shown to be present in both runoff and groundwater sources (Bahia-Oliveira et al. 2017). Digital elevation maps (DEM) were obtained for the study area using earth explorer (https://earthexplorer.usgs.gov/). Multiple DEM images were required to sufficiently cover the study area, and separate DEMs were combined using Qgis 3.2.3-Bonn (QGIS 2019). The combined DEM was projected into NAD83 Universal transverse Mercator (UTM) zone $10 \mathrm{~N}$. The Projected DEM was manipulated using the GRASS GIS (GRASS 2017) toolset by removal of sinks, generation of a flow accumulation raster and water outlet to delineate watersheds. Sinks in the DEM were filled using GRASS r.fill flow accumulation and direction raster was generated using GRASS r.watershed resulting in river course map and watershed. Lastly, using the flow direction raster, the GRASS r.water.outlet tool was used to determine the water outlet point of the generated watershed.

Considering the proximity of opossum OP1 to an area of elevated land which separates two watersheds and that the flow of surface water is not necessarily tied to groundwater gradients, it was prudent to generate a groundwater contour map. The groundwater map was generated using data from the USGS groundwater monitoring program (U.S. Geological Survey 2018). A USGS dataset from summer 2016 was selected due to temporal proximity to the study period and good spatial coverage.
Using the bore locations in UTM (X, Y) and elevation (feet, $\mathrm{Z}$ ), an $\mathrm{X}, \mathrm{Y}, \mathrm{Z}$ grid was generated representing the groundwater surface. The surface grid was generated using a kriging method in surfer 15 (Golden Software, Golden, CA).

\section{Results}

\section{Marine Mammals}

The species of stranded marine mammals included in the study are summarized in Table 1 . Figure 1 depicts the stranding location of marine mammals that tested positive for Sarcocystis spp. Sequence analysis confirmed S. neurona infections in 12 marine mammals, yielding an overall prevalence of $40 \%$ (Table 1 and Table S1). In two northern sea otter samples, $\mathrm{SO} 4$ and $\mathrm{SO} 3, \mathrm{DNA}$ amplification yielded products consistent in size with Sarcocystis, however, sequencing failed, and thus no molecular confirmation was possible. Therefore, $\mathrm{SO} 4$ and $\mathrm{SO} 3$ were not reported as S. neurona-infected marine mammals in this study. In one harbor seal (HS7), DNA amplified via the ITS1 assay was determined to have $100 \%$ identity with Sarcocystis pinnipedi (GenBank No. MT460246) (Haman et al. 2013; Miller et al. 2018). Simultaneous protozoal infections in dam and neonate were observed in a sea lion 1 (SL1) and her inutero fetus (SL1F) with S. neurona, and in HP4 (dam) and HP4F (fetus) with T. gondii. Of the 20 animals tested with primers that could identify Sarcocystis and T. gondii, one harbor porpoise (HP4) was co-infected with S. neurona and T. gondii, yielding a $5 \%$ prevalence of dual protozoan infection. Overall, 4 marine mammals (HP4, HP4F, SO3, DP1) were infected with $T$. gondii $(20 \% \%$ prevalence $)$ (Table S1).

\section{Opossums}

Figure 1 depicts the location of opossums that tested positive for Sarcocystis spp. Of the 32 opossums, 9 had sporocysts visualized in GI scrapings using microscopy. Nucleic acid amplification products from three (9.4\%) of these samples were confirmed via sequence analysis as $S$. neurona, four (12.5\%) were confirmed as Sarcocystis falcatula and OP21 contained sporocysts that yielded a DNA sequence consistent with Sarcocystis sp. AGP-1 (GenBank accession no. DQ768306.1; 100\% identity). In one sample containing sporocysts (OP5), sequencing attempts failed, 
Table 1. Prevalence of Sarcocystis neurona in Opossums and Marine Mammals Sampled in Western Washington State, USA between 2015 and 2017

\begin{tabular}{|c|c|c|c|c|c|c|}
\hline $\begin{array}{c}\text { Animal } \\
\text { type }\end{array}$ & Scientific Name & Common name & $\begin{array}{l}\text { No. of } \\
\text { Animals }\end{array}$ & $\begin{array}{l}\text { No positive for } S \text {. neurona } \\
\text { (prevalence) }\end{array}$ & $\begin{array}{l}\text { Other Sarcocystis } \\
\text { spp found }\end{array}$ & $\begin{array}{l}\text { Tissue } \\
\text { Tested }^{\mathrm{a}}\end{array}$ \\
\hline Opossum & $\begin{array}{l}\text { Didelphis virgini- } \\
\text { ana }\end{array}$ & Opossum & 32 & $3(9.4 \%)$ & $\begin{array}{l}\text { S. falcatula }(n=4) \\
\text { S. AGP-1 }(n=1)\end{array}$ & GIS \\
\hline Marine & Eumetopias jubatus & Steller sea lion & 3 & $2(66.6 \%)$ & & B \\
\hline \multirow[t]{8}{*}{ Mammal } & Enhydra lutris & Northern sea otter & 5 & $1(20 \%)$ & & B \\
\hline & Pusa hispida & Ringed seal & 1 & $0(0 \%)$ & & B \\
\hline & Phoca vitulina & Harbor seal & 11 & $3(27 \%)$ & $\begin{array}{l}\text { S. } \text { pinnipedi }^{\mathrm{b}} \\
\quad(n=1)\end{array}$ & $\begin{array}{l}\mathrm{B}, \mathrm{M} \\
\quad(n=2)\end{array}$ \\
\hline & Phocoena phocoena & Harbor Porpoise & 6 & $4(66.6 \%)$ & & B \\
\hline & $\begin{array}{l}\text { Arctocephalus } \\
\text { townsendi }\end{array}$ & Guadalupe fur seal & 1 & $0(0 \%)$ & & B \\
\hline & Phocoenoids dalli & Dall porpoise & 1 & $0(0 \%)$ & & B \\
\hline & Delphinus capensis & $\begin{array}{l}\text { Long-beaked com- } \\
\text { mon dolphin }\end{array}$ & 1 & $1(100 \%)$ & & B \\
\hline & $\begin{array}{l}\text { Lagenorhynchus } \\
\text { obliquidens }\end{array}$ & $\begin{array}{l}\text { Pacific white-sided } \\
\text { dolphin }\end{array}$ & 1 & $1(100 \%)$ & & B \\
\hline
\end{tabular}

${ }^{\mathrm{a}}$ GIS = gastrointestinal scraping, $\mathrm{B}=$ brain tissue, $\mathrm{M}=$ skeletal muscle

${ }^{\mathrm{b}}$ GenBank accession no. MT460246

and thus this sample was not included in further genetic characterization.

\section{Molecular Characterization of S. neurona}

Further molecular characterization of $S$. neurona was performed in the 12 marine mammals and 3 opossums that were confirmed to be infected. Single nucleotide polymorphisms (SNPs) in one polymorphic gene (SnSAG3) and variations in dinucleotide repeats in three microsatellite markers are reported in Table 2. Sequence analysis of the snSAG3 gene demonstrated seven SNPs at nucleotide position 239, 506, 507, 508, 509, 735 and 1057. Dinucleotide repeats at the sn9 microsatellite showed little polymorphism, with only two variants, while sn7 had the highest variability with four variants. Genetic identity was confirmed across these four genetic markers among two opossums (OP1 and OP3) and one harbor porpoise (HP2).

\section{Watershed and Groundwater Pathway Mapping}

Hydrological mapping was conducted for the two opossums (OP1 and OP2) that were shedding sporocysts bearing the same $S$. neurona genotype as HP2; no hydrological connection was observed between OP2 and HP2 (data not shown). For OP1, S. neurona sporocysts were estimated to travel toward the east in two pathways, via groundwater and surface water. Sporocysts entrained in surface water following rainfall events were likely to travel in overland runoff southward to a topographic low, eventually moving due east toward the Totten Inlet (Fig. 2), which is hydrologically connected to the water body in which HP2 stranded. The groundwater contour map showed a similar direction of water flow (Fig. 2). Sporocysts originating from OP1 feces that were not entrained in overland flow could infiltrate soil vertically to the groundwater table. Once sporocysts reached the water table, they would flow within the underground water gradient toward the east, and ultimately exit into the Totten Inlet.

\section{DIscussion}

This study demonstrates for the first time the presence of $S$. neurona in opossums in western Washington, with a prevalence of $9.4 \%$ actively shedding sporocysts. We have identified molecular linkages between $S$. neurona shed by terrestrial opossums and parasite genotypes in infected marine mammals in the Pacific Northwest in two ways. First, genetic identity was found between two opossums 
Table 2. Molecular Characterization of Sarcocystis neurona in Marine Mammals and Opossums

\begin{tabular}{|c|c|c|c|c|c|c|c|c|c|c|c|}
\hline \multirow[t]{3}{*}{ Animal type } & \multirow[t]{3}{*}{ Animal ID ${ }^{\mathrm{a}}$} & \multicolumn{10}{|c|}{ Genetic marker analyzed } \\
\hline & & \multicolumn{3}{|c|}{ Microsatellite } & \multicolumn{7}{|c|}{ snSAG3 } \\
\hline & & $\begin{array}{l}\text { sn7 } \\
(\mathrm{CA}) \mathrm{n}\end{array}$ & $\begin{array}{l}\text { sn3 } \\
(\mathrm{AT}) \mathrm{n}\end{array}$ & $\begin{array}{l}\text { sn9 } \\
(\mathrm{GT}) \mathrm{n}\end{array}$ & 239 & 506 & 507 & 508 & 509 & 735 & 1057 \\
\hline \multirow[t]{12}{*}{ Marine Mammal } & SL1 & 22 & * & 14 & $\mathrm{C}$ & $\mathrm{T}$ & DEL & DEL & $\mathrm{T}$ & $\mathrm{T}$ & $\mathrm{T}$ \\
\hline & $\mathrm{SL}_{1} \mathrm{~F}^{\mathrm{b}}$ & 22 & 11 & 14 & * & & & & & & \\
\hline & SO1 & * & 12 & * & * & & & & & & \\
\hline & HS1 & * & * & * & * & & & & & & \\
\hline & $\mathrm{HS} 2^{\mathrm{c}}$ & 22 & 10 & 14 & G & DEL & DEL & DEL & DEL & $\mathrm{C}$ & $\mathrm{T}$ \\
\hline & HS3 & * & * & * & * & & & & & & \\
\hline & HP1 & 23 & 11 & 14 & $\mathrm{C}$ & $\mathrm{T}$ & A & $\mathrm{T}$ & A & $\mathrm{T}$ & $\mathrm{C}$ \\
\hline & HP2 & 22 & 11 & 14 & $\mathrm{C}$ & $\mathbf{T}$ & A & $\mathbf{T}$ & A & $\mathbf{T}$ & $\mathrm{C}$ \\
\hline & HP3 & 25 & - & - & G & $\mathrm{T}$ & A & $\mathrm{T}$ & A & $\mathrm{T}$ & $\mathrm{C}$ \\
\hline & HP4 & 23 & 11 & 14 & $\mathrm{C}$ & $\mathrm{T}$ & A & $\mathrm{T}$ & A & $\mathrm{T}$ & $\mathrm{C}$ \\
\hline & PWSD1 & 22 & 10 & 14 & G & DEL & DEL & DEL & DEL & $\mathrm{C}$ & $\mathrm{C}$ \\
\hline & LBCD1 & $\star$ & $\star$ & * & $\star$ & & & & & & \\
\hline \multirow[t]{3}{*}{ Opossum } & OP1 & 22 & 11 & 14 & $\mathrm{C}$ & $\mathbf{T}$ & A & $\mathbf{T}$ & A & $\mathbf{T}$ & $\mathrm{C}$ \\
\hline & OP2 & 21 & 11 & 14 & $\mathrm{C}$ & $\mathrm{T}$ & A & $\mathrm{T}$ & A & $\mathrm{T}$ & $\mathrm{C}$ \\
\hline & OP3 & 22 & 11 & 14 & $\mathrm{C}$ & $\mathbf{T}$ & A & $\mathbf{T}$ & A & $\mathbf{T}$ & C \\
\hline
\end{tabular}

The nucleotide shown beneath the snSAG3 genetic markers indicates polymorphic sites among the S. neurona strains. DEL indicates deletions; asterisk $\left({ }^{*}\right)$ indicates no amplification. Bolded text denotes animals sharing genetic identity among examined loci for $S$. neurona

${ }^{a}$ SL $=$ Sea Lion, SO = Sea Otter, PWSD = Pacific White-Sided Dolphin, HS = Harbor Seal, HP = Harbor Porpoise, LBCD = Long-Beaked Common Dolphin, OP = Opossum

${ }^{\mathrm{b}} \mathrm{F}$ detonates the neonatal fetus of the corresponding mammal

${ }^{c}$ HS2 matches genotype XIII described in Barbosa et al. (2015)

(OP1 and OP2) and a harbor porpoise (HP2) across four genetic markers (snSAG3, sn3, sn7, sn9). Second, in the first hydrological source-to-sea connection study of $S$. neurona in the Pacific Northwest, watershed and groundwater mapping demonstrated hydrological pathways connecting sporocysts shed on land with coastal waters where infected marine mammals have stranded. Thus, we provide molecular and hydrological support for the land-to-sea flow of S. neurona in the Pacific Northwest. Of note, the opossums included in this study were obtained opportunistically as road-killed animals, and thus the $S$. neurona prevalence presented here may not reflect a true population prevalence.

Rejmanek et al. (2009) have previously reported the prevalence of $S$. neurona in opossums from central California to be less than $6 \%$ based on molecular detection of sporocysts in GI scrapings or feces. In their study, multiple risk factors for infection were identified, including adult age, a non-coastal location and collection of samples be- tween March and July (Rejmanek et al. 2009). As our current study included a more limited sample size of predominantly adult opossums and was performed on animals collected only between January and June, our ability to compare risk factors for seasonal and demographic variables was limited. Prevalence of $S$. neurona shedding in the eastern coast of the USA is reported to be higher at $14.9 \%$ 31.8\% (Elsheikha et al. 2004; Dubey 2000). The lower prevalence on the west coast of the USA has been attributed to the more recent introduction of opossums to the region and therefore the parasite may not be as prevalent in this population (Rejmanek et al. 2009).

Through molecular characterization of $S$. neurona in central California, Rejmanek et al. (2010) demonstrated that opossums shed sporocysts that are molecularly identical to strains obtained from marine mammal tissues. Here, we report a similar potential molecular link as we identified two opossums (OP1 and OP2) and one harbor porpoise (HP2) that shared genetic identity across four 


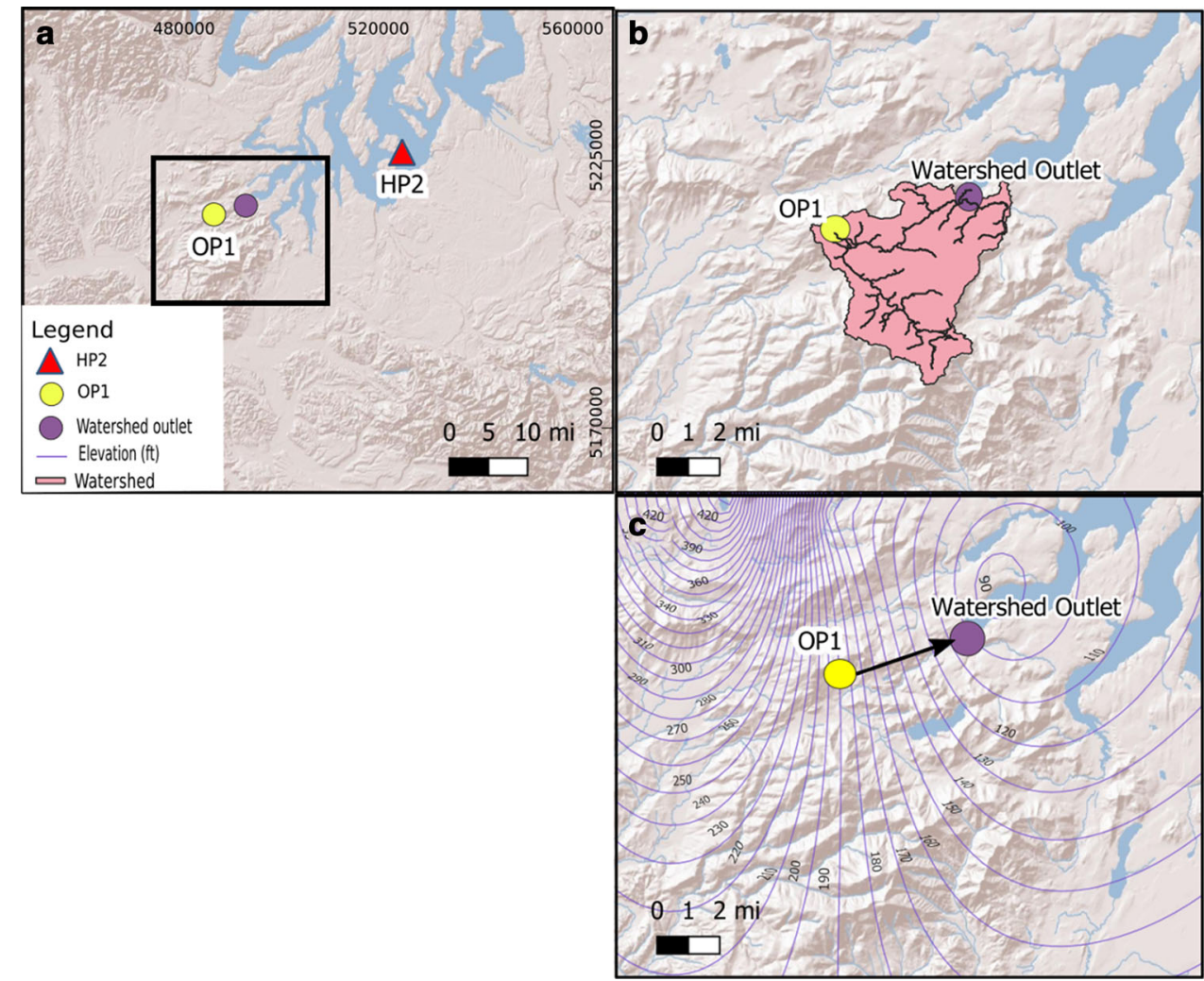

Figure 2. a Map depicting study region (inset) in Washington State, USA. b Watershed map with pink indicating the water flow from the site where an S. neurona-positive opossum (OP1) was collected to the Totten inlet (purple circle). This body of water is directly linked with the region where a harbor porpoise (HP2) carcass was shown to be infected with $S$. neurona that shared identical sequences among the four targeted loci. c Groundwater map depicting flow of groundwater (black arrow) from the sampling location of OP1 into coastal waters where HP2 had stranded.

genetic markers (snSAG3, sn3, sn7, sn9). We further investigated hydrological connections in the study area to evaluate if the physical flow of runoff from the terrestrial definitive hosts on land could be traced to the stranding locations of infected marine mammals. Watershed modeling has been used help predict movement of land-based pathogens from source to sea (VanWormer et al. 2016). The hydrological maps that we produced in this study suggest that $S$. neurona sporocysts shed in the feces of OP1 may travel via two pathways, in groundwater or surface water, both in an easterly direction toward the Totten Inlet (Fig. 2B). Transport of sporocysts through groundwater depends on a multitude of factors, including sporocyst charge and soil type (Dumètre et al. 2011). Closely related protozoal parasites such as $T$. gondii have been found in ground and surface water, thus demonstrating that fecally shed parasites similar in size and shape to S. neurona can infiltrate groundwater (Bahia-Oliveira et al. 2017). Both pathways could result in contaminated waters flowing into the Totten Inlet that hydrologically connects with the Carr Inlet, where HP2 had stranded.

While the projected hydrological transport pathways of sporocysts from the opossum to a stranded, infected marine mammal supports our molecular findings, there are factors that should be considered when investigating landto-sea pathogen transmission. First, the stranding location of HP2 may differ from location of exposure; it is thus possible that infection has occurred several weeks earlier in a different coastal site, or even months to years earlier if the infection was chronic in nature. Further pathological examination to establish chronicity of protozoal infection in stranded marine mammals was beyond the scope of this study but should be investigated in the future. There is also the possibility that carcasses can drift post-mortem, and thus locations where their bodies were recovered may not represent location of death or exposure. Movement of sporocysts may also occur through paratenic hosts if those are mobile (e.g., fish). To date, the only lower tropic animals in which $S$. neurona has been detected are mussels 
(Michaels et al. 2016); however, studies investigating S. neurona in marine food webs are scarce.

Genetic characterization S. neurona based on the snSAG3 gene and microsatellite (MS) markers (sn3, sn7 and sn9) was chosen as they were previously reported to be more polymorphic among the 13 genetic markers analyzed by Rejmanek et al. (2010). Three of the markers (snSAG, sn3 and sn9) analyzed in this study were also included in a study by Barbosa et al. (2015), and the genetic profile at these markers in one harbor seal (HS2) was consistent with the novel S. neurona genotype XIII (Barbosa et al. 2015). In their study, Barbosa et al. (2015) identified the presence of genotype XIII in 12 marine mammals from the outer Washington coast: one harbor porpoise, one Steller sea lion and 10 Pacific harbor seals. Each of these 12 cases had marked to severe protozoal encephalitis, leading the authors to conclude that this genotype is likely to be a more virulent parasite strain (Barbosa et al. 2015). Our current finding of genotype XIII in a harbor seal (HS2) collected in 2017 indicates the persistence of this genotype within the sampled marine mammal population.

Molecular sequencing at the ITS1 gene showed that one harbor seal (HS7) was infected with S. pinnipedi, a novel Sarcocystis species that was implicated as a cause of necrotizing hepatitis and associated mortality in ringed seals, Pacific walrus (Odobenus rosmarus divergens), bearded seal (Erignathus barbatus), spotted seal (Phoca largha) and gray seals (Halichoerus grypus) (Haman et al. 2015). Previous work has suggested a close evolutionary relationship between $S$. pinnipedi and S. canis, which has been described in dogs and bears (Dubey et al. 2006a, b; Britton et al. 2019; Davies et al. 2011). Sarcocystis pinnipedi was initially isolated in gray seals after a mass mortality event in Nova Scotia, Canada in March 2012. This study is the first report of $S$. pinnipedi infection in a harbor seal and the identification of this pathogen in the northwest Pacific Ocean indicates that the range of $S$. pinnipedi is not restricted to the Atlantic or Arctic Oceans where it was first identified.

While the apparent prevalence of $S$. neurona in the tested marine mammals was $40 \%(n=30)$, the population of animals included in this study was considered nonrandom based on the inclusion criteria previously defined in the methods section. Therefore, the overall prevalence of $S$. neurona in the general marine mammal population in this region cannot be estimated from this work. A similar report that tested for S. neurona infection in a non-random marine mammal population in the Pacific Northwest re- ported a higher prevalence of $61.5 \%$ (Gibson et al. 2011). Specifically, for sea otters in the Washington Olympic peninsula, S. neurona prevalence has been shown to be $67 \%$ using indirect fluorescent antibody testing (Burgess et al. 2020).

In the subset of marine mammal samples that was tested for the presence of both S. neurona and T. gondii DNA $(n=20)$ using the pan apicomplexan ITS1 primer set, T. gondii was present in $20 \%$ and S. neurona in $35 \%$ of animals. This finding supports other studies that noted a relative higher prevalence of $S$. neurona infections compared with $T$. gondii in marine mammals from the Pacific Northwest (Gibson et al. 2011; Thomas et al. 2007). Only one harbor porpoise (HP4) had a co-infection with both $S$. neurona and T. gondii (5\% prevalence). Other studies have reported higher prevalence of co-infection, at $42 \%$ (Gibson et al. 2011) and $30.8 \%$ in sea otters (Thomas et al. 2007; White et al. 2018).

Of the four pregnant females with unborn fetuses included in this study, three tested positive for S. neurona, one of which was the aforementioned HP4 animal co-infected with T. gondii. Horizontal transmission is considered to be the primary route of $T$. gondii transmission; however, vertical transmission has also been documented and has been hypothesized to play an important role in the epidemiology of the parasite (Shapiro et al. 2016; Miller et al. 2008; Barbosa et al. 2015). Data from this study further support the occurrence of $T$. gondii vertical transmission in marine mammals, with the presence of one congenitally infected fetus. In contrast with $T$. gondii, there are more limited reports on $S$. neurona vertical transmission. These include congenital infections in a sea otter (Shapiro et al. 2016), harbor porpoise, Steller sea lion, pygmy sperm whale and five harbor seals (Barbosa et al. 2015). Of the three $S$. neurona-positive dams in the current study, vertical transmission was documented in one sea lion, SL1 and her in-utero fetus SL1F (prevalence of 33.3\%, $n=3$ ). Further investigations are needed to evaluate the importance of vertical transmission in the epidemiology of $S$. neurona in marine mammals.

An unexpected finding from sequence analysis at the ITS1-500 locus was identification of one opossum to be infected with Sarcocystis sp. AGP-1. The AGP-1 species was previously identified in a client-owned 10 -year-old female African gray parrot which was attacked by an opossum (Delphis spp.) in Costa Rica and died one year later (Dubey et al. 2006a, b). This strain was found to be genetically different from S. neurona; however, molecular and phylo- 
genetic analyses by Dubey et al. (2016) have suggested that the opossum may serve as a definitive host for this species. To our knowledge, there have been no previous reports of Sarcocystis sp. AGP-1 detection in GI scrapings from an opossum, nor have there been any previous reports of this species outside of Costa Rica. Thus, the results presented here provide the first report of a sequence consistent with Sarcocystis sp. AGP-1 at the ITS1-500 locus collected from an opossum. Further molecular characterization would be required to further investigate genetic similarity.

As the opossum is a non-native species to Washington, the introduction of this species is likely associated with the emergence of $S$. neurona in endemic wildlife, both terrestrial and marine (Barbosa et al. 2015). A similar link has been shown with the introduction of domesticated cats into Hawaii (USA), which likely resulted in the introduction of T. gondii. Subsequently, T. gondii associated mortality has been identified in a number of endangered species, both terrestrial and marine, including the critically endangered Hawaiian monk seal (Neoonachus schauinislandi) (Barbieri et al. 2016; Honnold et al. 2005). Similarly, the northern expanding range of opossums and associated introduction of S. neurona to the Pacific Northwest may have resulted in increased detrimental outcome to naïve marine wildlife.

\section{CONCLUSION}

This study provides the first report of S. neurona in opossums from western Washington State, USA. Our results demonstrate molecular and hydrological evidence of transmission pathways of $S$. neurona from opossums to marine mammals in the Pacific Northwest, further supporting land-sea transmission of a protozoan parasite that can have detrimental impacts on marine wildlife. Investigations that identify specific temporal and spatial parameters associated with $S$. neurona infections in opossums may further assist targeted mitigation strategies for reducing the burden of $S$. neurona illness in susceptible hosts, including marine mammals.

\section{ACKNOWLEDGEMENTS}

This research was made possible through the University California Davis STAR program and was funded in part via a FVE/Merck scholarship awarded. We thank Brittany Dalley and Andrea Packham for laboratory support and Dr.
Patricia Conrad for facilitating research and staff. Funding and support for the marine mammal and opossum carcass collection and necropsy were provided by the Washington Department of Fish and Wildlife and the John H. Prescott Marine Mammal Rescue Assistance Grant Program. We thank all the volunteers and staff at the Washington Department of Fish and Wildlife and Cascadia Research Collective, especially Jessie Huggins, as well as responders from the Whatcom Marine Mammal Stranding Network (WMMSN). We also thank Dr. Michael Garner of Northwest ZooPath for contribution of pathology data.

\section{Open Access}

This article is licensed under a Creative Commons Attribution 4.0 International License, which permits use, sharing, adaptation, distribution and reproduction in any medium or format, as long as you give appropriate credit to the original author(s) and the source, provide a link to the Creative Commons licence, and indicate if changes were made. The images or other third party material in this article are included in the article's Creative Commons licence, unless indicated otherwise in a credit line to the material. If material is not included in the article's Creative Commons licence and your intended use is not permitted by statutory regulation or exceeds the permitted use, you will need to obtain permission directly from the copyright holder. To view a copy of this licence, visit http://creativec ommons.org/licenses/by/4.0/.

\section{REFERENCES}

Arkush JD, Miller MA, Leutenegger CM, Gardener IA, Packham AE, Heckeroth AR, Tenter AM, Barr BC, Conrad PA (2003) Molecular and bioassay-detection of Toxoplasma gondii oocyst uptake by mussels (Mytilus galloprovincialis). International Journal of Parasitology. 34:1185-1196

Asmundsson IM, Dubey JP, Rosenthal BM (2006) A genetically diverse but distinct North American population of Sarcocystis neurona includes an overrepresented clone described by 12 microsatellite alleles. Infection Genetics and Evolution. 6:352-360

Asmundsson IM, Rosenthal BM (2006) Isolation and characterization of microsatellite markers from Sarcocystis neurona, a causative agent of equine protozoal myeloencephalitis. Molecular Ecology Notes 6:8-10

Bahia-Oliveira L, Gomez-Marin J, and Shapiro K. (2017). Toxoplasma gondii. In: J.B. Rose and B. Jiménez-Cisneros, (eds) Global Water Pathogen Project. http://www.waterpathogens.or g (R. Fayer and W. Jakubowski, (eds) Part 3 Protists) http:// 
www.waterpathogens.org/book/toxoplasma-gondii Michigan State University, E. Lansing, MI, UNESCO.

Barbieri M, Kashinsky L, Rotstein D, Colegrove K, Haman K, Magargal S, Sweeny A, Kaufman A, Grigg M, Littnan C (2016) Protozoal-related mortalities in endangered Hawaiian monk seals Neomonachus schauinslandi. Dis. Aquat. Org. 121:85-95

Barbosa L, Johnson C, Lambourn D, Gibson A, Haman K, Huggins J, Sweeny A, Sundar N, Raverty S, Grigg M (2015) A novel Sarcocystis neurona genotype XIII is associated with severe encephalitis in an unexpectedly broad range of marine mammals from the northeastern Pacific Ocean. International Journal for Parasitology 45(9-10):595-603

Britton AP, Bidulka J, Scouras A, Schwantie H, Joseph T (2019) Fatal hepatic sarcocystosis in a free-ranging grizzly bear cub associated with Sarcocystis canis-like infection. Journal of Veterinary Diagnostic Investigation 31(2):303-206

Burgess TL, Tinker MT, Miller MA, Smith WA, Bodkin JL, Murray MJ, Nichol LM, Saarienen JA, Larson S, Tomoleoni JA, Conrad PA, Johnson.,C.K. (2020) Spatial epidemiological patterns suggest mechanisms of land-sea transmission for Sarcocystis neurona in a coastal marine mammal. Sci Rep 10:3683

Conrad PA, Miller MA, Kreuder C, James ER, Mazet J, Dabritz H, Jessup DA, Gulland F, Grigg ME (2005) Transmission of Toxoplasma: Clues from the study of sea otters as sentinel of Toxoplasma gondii flow into the marine environment. International Journal of Parasitology 35:1155-1168

Davies JL, Haldorson GL, Bradway DS, Britton AP (2011) Fatal hepatic sarcocystosis in a captive black bear (Ursus americanus) associated with Sarcocystis canis-like infection. Journal of Veterinary Diagnostic Investigation. 23(2):379-383

Dubey JP (2000) Prevalence of Sarcocystis species in wild-caught opossums (Dedelphis virginiana). Journal of Parasitology 86(4):705-710

Dubey JP, Chapman JL, Rosenthal BM, Mense M, Scheuler RL (2006) Clinical Sarcocystis neurona, Sarcocystis canis, Toxoplasma gondii and Neospora caninum infections in dogs. Veterinary Parasitology 137(1-2):36-39

Dubey JP, Davis SW, Speer CA, Bowman DD, de Lahunta A, Granstrom DE, Topper MJ, Hamir AN, Cummings JF, Sutter MM (1991) Sarcocystis neurona sp. (Protozoa: Apicomplexa), the etiological agent of equine protozoal myeloencephalitis. Journal of Parasitology 777:212-218

Dubey JP, Rosenthal BM, Morales JA, Alfaro A. (2006) Morphologic and genetic characterization of Sarcocystis sp. from the African grey parrot, Psittacus erithacus, from Costa Rica, Acta Parasitologica, 51(3):161-168.

Dubey JP, Saville W, Lindsay D, Stich R, Stanek J, Speer C, Rosenthal B, Njoku C, Kwok O, Shen S, Reed S (2000) Completion of the Life Cycle of Sarcocystis neurona. Journal of Parasitology 86(6):1276-1280

Dubey JP, Saville WJ, Stanek JF, Lindsay DS, Rosenthal BM, Oglesbee MJ, Rosypal AC, Njoku CJ, Stich RW, Kwok OC, Shen SK, Hamir AN, Reed SM (2001) Sarcocystis neurona infections in raccoons (Procyon lotor): evidence for natural infection with sarcocysts, transmission of infection to opossums (Didelphis virginiana), and experimental induction of neurologic disease in raccoons. Veterinary Parasitology. 100:117-129

Dumètre A, Aubert D, Puech P, Hohweyer J, Azas N, Villena I (2011) Interaction forces drive the environmental transmission of pathogenic protozoa. Applied and Environmental Microbiology 78(4):905-912
Elsheikha HM, Murphy AJ, Mansfield LS (2004) Prevalence of Sarcocystis species sporocysts in Northern Virginia opossums (Didelphis virginiana). Parasitology Research 93(5):427-431

Fenger C, Granstrom D, Langemeier J, Stamper S, Donahue J, Patterson J, Gajadhar A, Marteniuk J, Xiaomin Z, Dubey J (1995) Identification of Opossums (Didelphis virginiana) as the putative definitive host of Sarcocystis neurona. The Journal of Parasitology 81(6):916

Gibson AK, Raverty S, Lambourn DM, Huggins J, Magargal SL, et al. (2011) Polyparasitism is associated with increased disease severity in Toxoplasma gondii-infected marine sentinel species. PLoS Neglected Tropical Diseases 5(5):e1142

GRASS Development Team, 2017. Geographic Resources Analysis Support System (GRASS) Software, Version 7.2. Open Source Geospatial Foundation. Electronic document: http://grass.osge o.org

Haman KH, Raverty S, Daoust P, St. Leger J, Hammill M, Fenton H, Grigg ME (2013) Novel Sarcocystis spp. associated with mortality in pinnipeds of the North Atlantic and Pacific Oceans. In: International Association for Aquatic Animal Medicine, April 21-26 2013, Sausalito, California.

Honnold SP, Braun R, Scott DP, Sreekumar C, Dubey JP (2005) Toxoplasmosis in a Hawaiian monk seal (Monachus schauinslandi). Journal of Parasitology. 91:695-697

Kreuder C, Miller M, Jessup D, Lowenstine L, Harris M, Ames J, Carpenter T, Conrad P, Mazet J (2003) Patterns of mortality in southern sea otters (Enhydra lutris nereis) from 1998-2001. Journal of Wildlife Diseases 39(3):495-509

Michaels L, Rejmanek D, Aguilar B, Conrad P, Shapiro K (2016) California mussels (Mytilus californianus) as sentinels for marine contamination with Sarcocystis neurona. Parasitology 143:762-769

Miller MA, Grigg ME, Kreuder C, James ER, Melli AC, Crosbie PR, Jessup DA, Boothroyd JC, Brownstein D, Conrad PA (2004) An unusual genotype of Toxoplasma gondii is common in California sea otters (Enhydra lutris nereis) and is a cause of mortality. International Journal for Parasitology 34(3):275-284

Miller M, Barr B, Nordhausen R, James E, Magargal S, Murray M, Conrad P, Toy-Choutka S, Jessup D, Grigg M (2009) Ultrastructural and molecular confirmation of the development of Sarcocystis neurona tissue cysts in the central nervous system of southern sea otters (Enhydra lutris nereis). International Journal for Parasitology 39(12):1363-1372

Miller MA, Conrad PA, Harris M, Hatfield B, Langlois G, Jessup DA, Magargal SL, Packham AE, Toy-Choutka S, Melli AC, Murray MA, Gulland FM, Grigg ME (2010) A protozoal-associated epizootic impacting marine wildlife: Mass-mortality of southern sea otters (Enhydra lutris nereis) due to Sarcocystis neurona infection. Veterinary Parasitology 172(3-4):183-194

Miller M, Conrad P, James ER, Packham A, Toy-Choutka S, Murray AJ, Jessup D, Grigg M (2008) Transplacental toxoplasmosis in a wild southern sea otter (Enhydra lutris nereis). Veterinary Parasitology 153(1-2):12-18

Miller MA, Shapiro K, Murray M, Haulena MJ, and Raverty S. (2018) Protozoan parasites of marine mammals. In $C R C$ Handbook of Marine Mammal Medicine. Frances M.D. Gulland, Leslie A. Dierauf, and Whitman, K.L. (eds): CRC Press, pp. 425470.

Mullaney T, Murphy A, Kiupel M, Bell J, Rossano M, Mansfield L (2005) Evidence to support horses as natural intermediate hosts for Sarcocystis neurona. Veterinary Parasitology 133(1):27-36 
QGIS Development Team (QGIS) (2019). QGIS Geographic information system. Open Source Geospatial Foundation Project. http://qgis.org/en/site

Rejmanek D, Miller M, Grigg M, Crosbie P, Conrad P (2010) Molecular characterization of Sarcocystis neurona strains from opossums (Didelphis virginiana) and intermediate hosts from Central California. Veterinary Parasitology 170(1-2):20-29

Rejmanek D, Vanwormer E, Miller M, Mazet J, Nichelason A, Melli A, Packham A, Jessup D, Conrad P (2009) Prevalence and risk factors associated with Sarcocystis neurona infections in opossums (Didelphis virginiana) from central California. Veterinary Parasitology 166(1-2):8-14

Schott KG, Krusor C, Tinker MT, Moore J, Conrad PA, Shapiro K (2016) Concentration and retention of Toxoplasma gondii surrogates from seawater by red abalone (Haliotis rufescens). Parasitology 143:1703-1712

Shapiro K, Krusor C, Mazzillo F, Conrad PA, Largier JL, Mazet JAK, Silver MW (2014) Aquatic polymers can drive pathogen transmission in coastal ecosystems. Proceedings of the Royal Society B 281(1795):20141287

Shapiro K, Miller MA, Packham AE, Aguilar B, Conrad PA, Vanwormer E, Murray MJ (2016) Dual congenital transmission of Toxoplasma gondii and Sarcocystis neurona in a late-term aborted pup from a chronically infected southern sea otter (Enhydra lutris nereis). Parasitology 143:276-288

Shapiro K, Silver MW, Largier JL, Conrad PA, Mazet JAK (2012) Association of Toxoplasma gondii oocysts with fresh, estuarine, and marine macroaggregates. Limnology and Oceanography 57(2):449-456
Thomas NJ, Dubey DP, Lindsay DS, Cole RA, Meteyer CU (2007) Protozoal meningoencephalitis in sea otters (Enhydra lutris): a histopathological and immunohistochemical study of naturally occurring cases. Journal of Comparative Pathology 137(23):102-121

U.S. Geological Survey (2018) Groundwater information pages: U.S. Geological Survey database available online at https://wate r.usgs.gov/ogw/. (Accessed May 14, 2018).

VanWormer E, Carpenter TE, Singh P, Shapiro K, Wallender WW, Conrad PA, Largier JL, Maneta MP (2016) Mazet JAK (2016) Coastal development and precipitation drive pathogen flow from land to sea: evidence from a Toxoplasma gondii and felid host system. Scientific Reports 6:29252

Wendte J, Miller M, Nandra A, Peat S, Crosbie P, Conrad P, Grigg M (2010) Limited genetic diversity among Sarcocystis neurona strains infecting southern sea otters precludes distinction between marine and terrestrial isolates. Veterinary Parasitology 169(1-2):37-44

Wendte J, Miller M, Lambourn D, Magargal S, Jessup D, Grigg M (2010) Self-mating in the definitive host potentiates clonal outbreaks of the Apicomplexan parasites Sarcocystis neurona and Toxoplasma gondii. PLoS Genetics 6(12):e1001261

White CL, Lankau E, Lynch D, Knowles S, Schuler K, Dubey J, Shearn-Bochsler V, Isidoro-Ayza M, Thomas N (2018) Mortality trends in Northern sea otters (Enhydra lutris kenyoni) collected from the coasts of Washington and Oregon, USA (2002-15). Journal of Wildlife Diseases 54(2):238-247 